\title{
PEMANFAATAN LIMBAH SERBUK BESI SEBAGAI AGREGAT HALUS PADA CAMPURAN ASPAL PANAS
}

\author{
Samsul Bahri ${ }^{1)}$ \\ ${ }^{1)}$ Dosen Program Studi Teknik Sipil, Fakultas Teknik UNIB, Jl. W. R. Supratman, \\ Kandang Limun, Bengkulu 38371, Telp. (0736)344087 \\ email: sbahri1972@yahoo.co.id
}

\begin{abstract}
Abstrak
Memanfaatkan suatu limbah industri untuk mendapatkan nilai tambah, merupakan bentuk inovasi dalam suatu penelitian. Tujuan penelitian ini adalah mencari pengaruh dan perbandingan nilai karakteristik Marshall antara campuran aspal panas normal dengan campuran aspal panas yang agregat halusnya diganti dengan limbah serbuk besi. Penelitian dilakukan di laboratorium dengan metode Marshall test. Komposisi penggantian agregat halus dengan limbah serbuk besi ditetapkan sebesar $0 \%, 25 \%, 50 \%, 75 \%$, dan $100 \%$. Hasil penelitian yang memenuhi spesifikasi kadar aspal optimum dan uji Marshall hanya variasi penggantian $0 \%$ dan variasi $25 \%$. Variasi $25 \%$ lebih unggul dalam pemenuhan parameter Marshall. Ketika agregrat halus diganti dengan limbah serbuk besi sebesar 25\%, terjadi efisiensi penggunaan aspal sebesar 17,86\%. Dengan demikian limbah serbuk besi dapat dimanfaatkan sebagai pengganti agegrat halus dalam campuran aspal (PANAS) dengan kadar maksimum $25 \%$.
\end{abstract}

Kata kunci: campuran aspal panas, serbuk besi, parameter Marshall

\begin{abstract}
One of innovation in research is utilizing an industrial waste to obtain value-added. The purpose of this study is to find the effect of and Marshall characteristic value comparison between normal asphalt hotmix and the one which fine aggregate is replaced with waste iron filings. The study was conducted in the laboratory to test Marshall method. The composition of fine aggregate replacement with waste iron powder set at 0\%, 25\%, 50\%, 75\%, and 100\%. The result showed that variation which met the specifications of the optimum bitumen content and parameter were only variation of $0 \%$ and a variation of $25 \%$. Variation at $25 \%$ is superior in terms of the fulfillment of the Marshall parameters. When the fine aggregate replaced with iron filings waste by $25 \%$, the use of bitumen was more efficient at $17.86 \%$. Therefore, waste iron powder can be used as a substitute for the refined agegrat A mixture of asphalt with a maximum level of $25 \%$.
\end{abstract}

Keywords: asphalt hotmix, iron powder, parameters marshall 


\section{PENDAHULUAN}

Sektor transportasi khususnya transportasi darat ibaratnya adalah urat nadi kehidupan bangsa dan rakyat Indonesia. Keberadaan transportasi darat menduduki tempat yang strategis karena segala bidang kegiatan dapat berjalan dengan lancar jika performa sarana dan prasarana transportasi darat optimal. Harapan itu tidak sepenuhnya tercapai mengingat kondisi sebagian konstruksi jalan sangat memprihatinkan. Banyaknya jalanjalan yang rusak dengan berbagai penyebab menambah potret buruk prasarana jalan di Indonesia.

Usaha untuk memperbaiki konstruksi jalan secara kontinyu terus dilakukan. Berbagai inovasi dan temuan baru senantiasa dikembangkan dan diaplikasikan dalam usaha perbaikan dan optimalisasi prasarana jalan. Penelitian untuk mengkaji dan memanfaatkan potensi sumber daya yang tersedia secara nyata terus dilakukan. Penelitian untuk memanfaatkan limbah serbuk besi adalah bagian dari usaha tersebut.

Limbah serbuk besi adalah sisa potongan atau sisa dari pembubutan besi tuang dalam kegiatan industri. Limbah yang dihasilkan dari sisa bubut dibuang saja tanpa memikiran dampak negatif pada lingkungan. Penulis tertarik untuk melakukan penelitian lebih lanjut tentang pemanfaatan limbah serbuk besi pada campuran aspal panas jenis AC-BC.

\section{Campuran aspal panas}

Asphalt hotmix didefinisikan sebagai campuran aspal panas lapisan padat dimana jenisnya berupa lapisan pondasi, lapis perata dan lapis aus. Lapisan ini tersusun dari beberapa agregat dan bahan aspal yang dicampur secara panas (Direktorat Jenderal Bina Marga, 2010). Sedangkan menurut Saodang (2005) beton aspal adalah jenis perkerasan jalan yang terdiri dari campuran agregat dan aspal, dengan atau tanpa bahan tambahan. Material dicampur di tempat pencampuran pada suhu tertentu lalu diangkut ke lokasi, dihamparkan dan dipadatkan.

\section{Bahan penyusun aspal}

Rancangan campuran aspal terdiri dari hasil pencampuran agregat kasar, agregat halus, aspal dan filler sebagai bahan pengisi, dengan nilai perbandingan tertentu. Bahanbahan campuran aspal harus memenuhi ketentuan yang disyaratkan dalam spesifikasi (Direktorat Jenderal Bina Marga, 2010).

\section{Agregat}

Menurut Siswosoebrotho (2010), agregat bahan utama yang turut menahan beban yang diderita oleh bagian perkerasan jalan sehingga perlu digunakan bahan pengikat aspal yang sangat berpengaruh oleh mutu agregat. Menurut Direktorat Jenderal Bina Marga (2010) agregat terdiri dari agregat halus dan agregrat kasar.

\section{Aspal}

Aspal adalah material yang berwarna hitam atau coklat tua dan berfungsi sebagai bahan pengikat. Aspal pada temperatur ruang berbentuk padat sampai agak padat, sebagian besar terbentuk dari unsur hidrokarbon yang disebut bitumen, sehingga seringkali aspal disebut pula bitumenous material (Amal, 2011).

\section{Serbuk besi}

Biji besi yang didapatkan dari alam umumnya merupakan senyawa besi dengan oksigen seperti hematite $\left(\mathrm{Fe}_{2} \mathrm{O}_{3}\right)$, magnetite $\left(\mathrm{Fe}_{3} \mathrm{O}_{4}\right)$, limonite $\left(\mathrm{Fe}_{2} \mathrm{O}_{3}\right)$ atau siderite $\left(\mathrm{Fe}_{2} \mathrm{CO}_{3}\right)$. Pembentukan senyawa besi oksida tersebut sebagai proses alam yang terjadi selama beribu-ribu tahun. Kandungan senyawa besi dibumi ini mencapai 5\% dari seluruh kerak bumi ini. Serbuk besi adalah bagian dari hasil sisa potongan atau sisa pembubutan besi tuang yang merupakan hasil di pemakaian industri (Daryus, 2008). 


\section{Karakteristik aspal}

Menurut Sukirman (2007), karakteristik yang harus dimiliki dalam campuran aspal adalah stabilitas, durabilitas, fleksibilitas, ketahanan, kekesatan, kedap air dan workability.

1. Stabilitas lapisan perkerasan jalan adalah kemampuan lapisan perkerasan menerima beban lalu lintas tanpa terjadi perubahan bentuk tetap seperti gelombang, alur, dan bleeding.

2. Durabilitas adalah kemampuan beton aspal menerima repetisi beban lalu lintas dan gesekan antara roda kendaraan dengan permukaan jalan. Durabilitas dipengaruhi oleh selimut aspal, banyaknya pori dalam campuran, kepadatan dan kedap airnya campuran.

3. Fleksibilitas adalah kemampuan beton aspal untuk menyesuaikan diri akibat penurunan dan pergerakan dari pondasi atau tanah dasar, tanpa terjadi retak.

4. Ketahanan adalah kemampuan beton aspal menerima lendutan berulang akibat repetisi beban, tanpa terjadinya kelelahan berupa alur dan retak.

5. Kekesatan adalah kemampuan permukaan beton aspalmemberikan gaya gesek pada roda kendaraan sehingga kendaraan tidak tergelincir ataupun slip.

6. Kedap air merupakan kemampuan beton aspal untuk tidak dapat dimasuki air ataupun udara.

7. Workability merupakan kemampuan campuran beton aspal untuk mudah dihamparkan dan dipadatkan.Faktor yang mempengaruhi tingkat kemudahan dalam proses penghamparan dan pemadatan adalah viskositas aspal, kepekaan aspal terhadap perubahan temperatur, dan gradasi serta kondisi agregat.

\section{Pengujian Marshall}

Pengujian Marshall merupakan pengujian laboratorium yang meliputi pengujian karakteristik campuran dan perencanaan kadar aspal optimum (KAO). Ketentuan sifat-sifat campuran aspal beton (laston) menurut spesifikasi Direktorat Jenderal Bina Marga (2010) dapat dilihat pada Tabel 1.

Tabel 1. Ketentuan Sifat-Sifat Laston

\begin{tabular}{|c|c|c|c|c|}
\hline \multirow{2}{*}{\multicolumn{2}{|c|}{ Sifat-sifat campuran }} & \multicolumn{3}{|c|}{ Laston } \\
\hline & & \multirow{2}{*}{\multicolumn{2}{|c|}{\begin{tabular}{r|r}
$\mathrm{WC}$ & $\mathrm{BC}$ \\
& 1,2
\end{tabular}}} & \multirow[t]{2}{*}{ Base } \\
\hline $\begin{array}{c}\text { Penyerapan Aspal } \\
(\%)\end{array}$ & $\operatorname{Max}$ & & & \\
\hline \multicolumn{2}{|c|}{$\begin{array}{c}\text { Jumlah tumbukan } \\
\text { per bidang }\end{array}$} & \multicolumn{2}{|c|}{75} & 112 \\
\hline \multirow{2}{*}{$\operatorname{VIM}(\%)$} & Min & \multicolumn{3}{|c|}{3,5} \\
\hline & Max & \multicolumn{3}{|c|}{5,5} \\
\hline VFA (\%) & Min & 15 & 14 & 13 \\
\hline VMA (\%) & Min & 65 & 63 & 60 \\
\hline Stabilitas & Min & \multicolumn{2}{|c|}{800} & 1500 \\
\hline $\begin{array}{l}\text { Marshall } \\
(\mathrm{kg})\end{array}$ & $\operatorname{Max}$ & \multicolumn{2}{|c|}{-} & - \\
\hline $\begin{array}{l}\text { Flow } \\
(\mathrm{mm})\end{array}$ & Min & \multicolumn{2}{|c|}{3} & 5 \\
\hline $\begin{array}{c}\text { MQ } \\
(\mathrm{kg} / \mathrm{mm})\end{array}$ & Min & \multicolumn{2}{|c|}{250} & 300 \\
\hline $\begin{array}{c}\text { Stabilitas Marshall } \\
\text { sisa }(\%) \text { setelah } \\
\text { perendaman } 24 \\
\text { jam, } 60^{\circ} \mathrm{C}\end{array}$ & Min & \multicolumn{3}{|c|}{75} \\
\hline \begin{tabular}{|l|} 
Refusal \\
\end{tabular} & Min & \multicolumn{3}{|c|}{2,5} \\
\hline
\end{tabular}

Sumber: Departemen Pekerjaan Umum, 2005

\section{METODE PENELITIAN}

Penelitian ini menggunakan campuran Asphalt Concrete Binder Course (AC-BC) yang terdiri dari agregat kasar, agregat halus, aspal, filler dan limbah serbuk besi. Pengujian sifat-sifat campuran aspal dilakukan dengan Marshall test. Variasi penggantian agregat halus dengan limbah serbuk besi sebesar $25 \%, 50 \%$, $75 \%$, dan $100 \%$. Serbuk besi yang digunakan diseleksi sehingga memiliki gradasi yang sama dengan gradasi agregrat halus. Bahan utama filler berupa semen portland. Sedangkan aspal yang digunakan memiliki penetrasi $60 / 70$. 


\section{HASIL DAN PEMBAHASAN}

\section{Kadar Aspal Optimum (KAO)}

Berdasarkan hasil pengujian karakteristik Marshall didapat bahwa variasi yang memenuhi persyaratan spesifikasi Direktorat Jenderal Bina Marga (2010) adalah variasi $0 \%$ (kondisi normal) dan variasi $25 \%$. Nilai KAO untuk kondisi normal yaitu sebesar $5,60 \%$ dan nilai KAO untuk variasi $25 \%$ sebesar 4,60\%. Kondisi ini menunjukkan bahwa terjadi penghematan penggunaan aspal sebesar $17,86 \%$ ketika agregrat halus diganti dengan limbah serbuk besi sebesar $25 \%$.

\section{Karakteristik Marshall}

\section{Stabilitas}

Kemampuan perkerasan jalan ketika menerima beban lalu lintas tanpa mengalami perubahan bentuk merupakan syarat kelayakan suatu jalan. Perubahan bentuk yang dimaksud berupa gelombang, alur, dan bleeding. Stabilitas merupakan parameter yang digunakan untuk mengukur kekuatan lapisan perkerasan jalan.

Hasil penelitian memperlihatkan penggantian agregat halus dengan limbah serbuk besi sebesar $25 \%$ didapat nilai stabilitas sebesar 1122,6 kg. Sedangkan tanpa penggantian agregat halus atau kondisi normal stabilitasnya sebesar 1095,49 kg. Artinya terjadi peningkatan stabilitas sebesar 3,23\% akibat penggantian agregat halus dengan limbah serbuk besi sebesar 25\%. Nilai stabilitas kondisi tanpa penggantian (normal) dan variasi penggantian $25 \%$ ditampilkan dalam Gambar 1. Nilai stabilitas yang didapat berada diatas batas minimal spesifikasi Direktorat Jenderal Bina Marga (2010) yaitu minimum $800 \mathrm{~kg}$.

Peningkatan stabilitas akibat penggantian agregat halus dengan limbah serbuk besi sebesar $25 \%$ diperkirakan karena limbah serbuk besi mampu meningkatkan proses pengikatan agregrat oleh aspal. Besi bersifat konduktor, sehingga pada saat pencampuran aspal dalam kondisi panas, besi mampu mempercepat proses pemanasan dan mempertahankan suhunya.

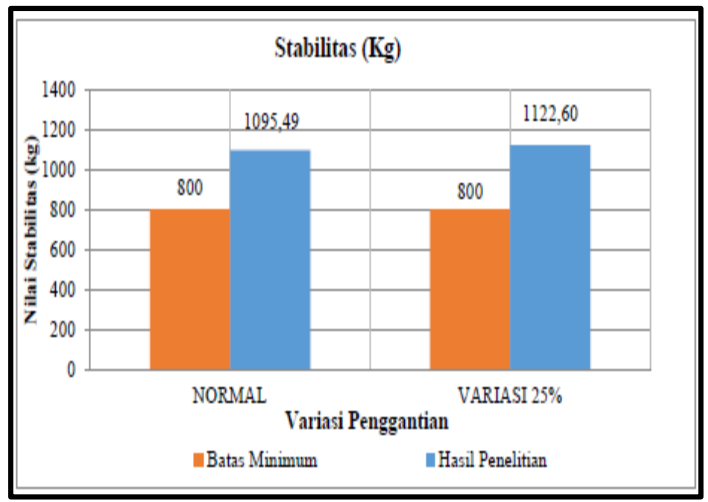

Gambar 1. Grafik Hubungan Stabilitas Variasi Penggantian dan Kondisi Normal

\section{Kelelehan (Flow)}

Saat perkerasan jalan menerima beban lalu lintas sampai batas keruntuhan, maka akan mengalami perubahan bentuk plastis yang dikenal dengan flow atau kelelehan. Besarnya nilai flow sangat dipengaruhi oleh besarnya kandungan aspal dalam campuran aspal. Flow yang rendah menandakan campuran tersebut memiliki rongga tak terisi aspal.

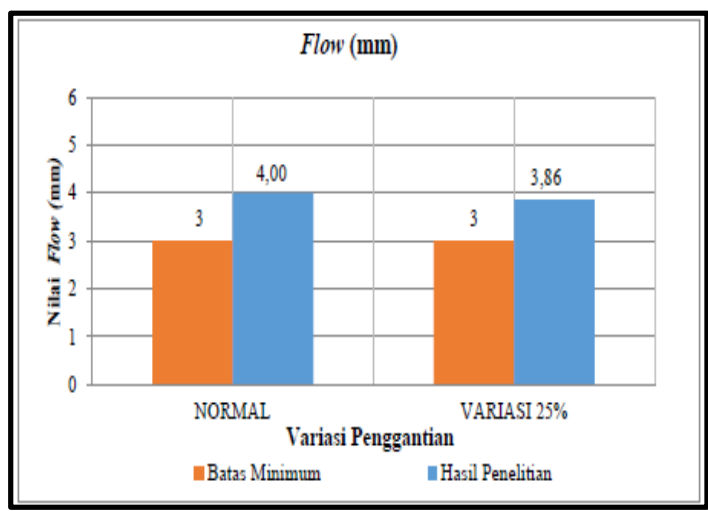

Gambar 2. Grafik Hubungan Flow dengan Variasi Penggantian dan Kondisi Normal

Gambar 2 menyajikan hasil pengujian nilai flow. Hasil penelitian menunjukkan bahwa tanpa penggantian agregat halus atau kondisi normal didapatkan nilai flow sebesar 
4,00 $\mathrm{mm}$. Penggantian agregat halus dengan limbah serbuk besi sebesar 25\% didapat nilai flow $3,86 \mathrm{~mm}$. Hasil tersebut memenuhi spesifikasi Direktorat Jenderal Bina Marga (2010) untuk kelelehan (flow) yaitu minimum $3 \mathrm{~mm}$.

\section{Voids in Mineral Aggregat (VMA)}

Tingkat kekakuan perkerasan jalan dapat diketahui dari nilai rongga dalam mineral agregat (Voids in Mineral Aggregat, VMA). Nilai VMA banyak terpengaruh oleh bentuk dan tekstur dari material agregat serta metode pemadatan yang digunakan.

Hasil dari pengujian didapat nilai VMA penggantian agregat halus dengan limbah serbuk besi $25 \%$ sebesar $14,31 \%$. Sedangkan tanpa penggantian agregat halus nilai VMA sebesar $14,76 \%$. Secara keseluruhan nilai VMA memenuhi persyaratan Direktorat Jenderal Bina Marga (2010) yaitu minimum 14\%. Hasil dari pengujian disajikan pada Gambar 3

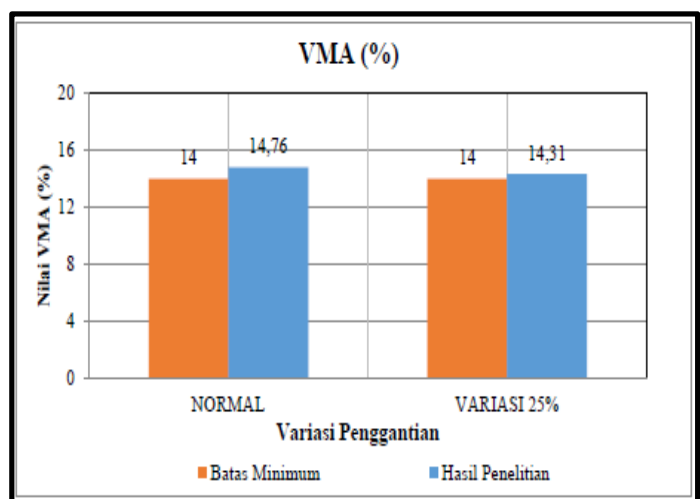

Gambar 3. Grafik Hubungan VMA dengan Variasi Penggantian dan Kondisi Normal

Nilai VMA penggantian limbah serbuk besi pada variasi $25 \%$ lebih rendah dibandingkan dengan tanpa penggantian. Ini berarti campuran aspal dengan penggantian limbah serbuk besi pada variasi $25 \%$ memiliki kekedapan lebih tinggi. Kondisi ini diperkirakan karena limbah serbuk besi mampu mengisi rongga-rongga campuran aspal secara baik.

\section{Voids Filled by Asphalt (VFA)}

Voids Filled by Asphalt (VFA) adalah volume pori beton aspal padat yang terisi oleh aspal, atau volume selimut aspal. Gambar 4 menunjukkan campuran dengan penggantian agregat halus dengan limbah serbuk besi $25 \%$ nilai VFA sebesar $67,56 \%$, nilai jauh lebih kecil dibandingkan tanpa dilakukan penggantian agregat halus dengan nilai VFA sebesar 79,43\%. Secara keseluruhan nilai VFA memenuhi persyaratan Direktorat Jenderal Bina Marga (2010) untuk VFA yaitu minimum 63\%.

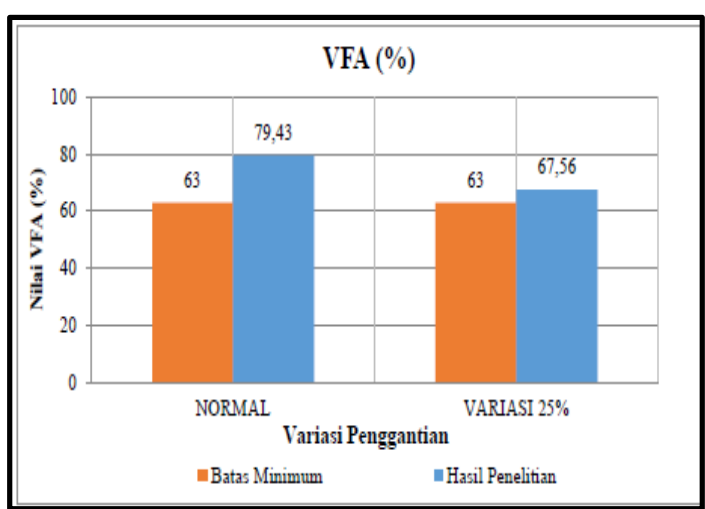

Gambar 4. Grafik Hubungan VFA dengan Variasi Penggantian dan Kondisi Normal

\section{Voids in Mixture (VIM)}

Saat perkerasan jalan mengalami pemadatan tambahan oleh repetisi beban lalu lintas atau aspal menjadi lunak akibat meningkatnya temperatur, maka dibutuhkan volume pori untuk bergeserkan butir-butir agregrat dalam rangka konsolidasi. Volume pori yang masih tersisa setelah campuran beton aspal dipadatkan disebut dengan Voids In Mixture (VIM).

Dari Gambar 5, hasil campuran dengan penggantian agregat halus dengan limbah serbuk besi $25 \%$ didapat nilai VIA sebesar $4,65 \%$ sedangkan tanpa dilakukan penggantian agregat halus nilai VIM sebesar $3,06 \%$. Secara keseluruhan nilai VIM memenuhi persyaratan Direktorat Jenderal Bina Marga (2010) untuk nilai VIM adalah $3-5 \%$. 


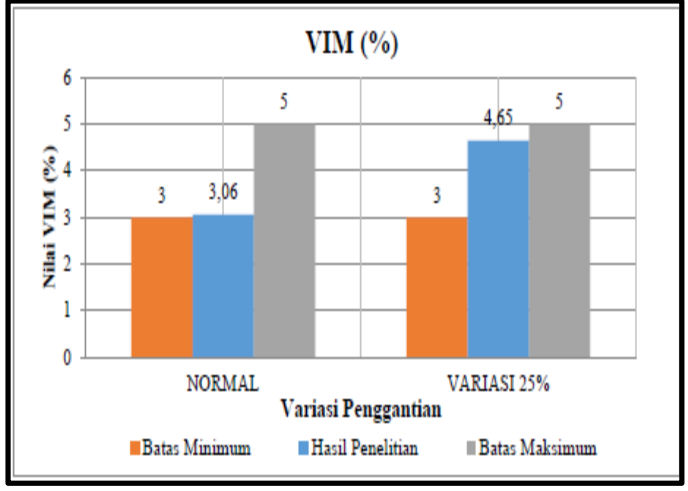

Gambar 5. Grafik Hubungan VIM dengan

Variasi Penggantian dan Kondisi Normal

Kemampuan campuran aspal pada kondisi penggantian maupun tanpa penggantian agregat halus untuk tetap mampu mempertahankan nilai VIM pada batas-batas yang disyaratkan menunjukkan kemampuan masing-masing material untuk mengisi rongga-rongga pori yang tercipta.

\section{Marshall Quotient (MQ)}

Perkerasan jalan yang unggul harus memiliki stabilitas yang mantap serta kelelehan yang cukup saat menerima repetisi beban lalu lintas. Keseimbangan antara nilai stabilitas dengan nilai kelelehan dinyatakan dengan nilai Marshall Quotient (MQ). Nilai MQ yang terlalu besar menunjukkan kekuatan campuran perkerasan tinggi dan kaku, berakibat mudahnya terjadi retakan, sebaliknya bila harga MQ terlalu kecil menunjukkan terlalu plastis yang berakibat mudah mengalami deformasi.

Penggantian agregat halus dengan limbah serbuk besi $25 \%$ didapatkan nilai MQ sebesar 291,43 kg/mm sedangkan tanpa penggantian nilainya hanya $275,81 \mathrm{~kg} / \mathrm{mm}$. Secara keseluruhan nilai MQ memenuhi persyaratan Direktorat Jenderal Bina Marga (2010) yaitu minimum $250 \mathrm{~kg} / \mathrm{mm}$.

Berdasarkan Gambar 6 nilai MQ dengan penggantian $25 \%$ lebih tinggi dibandingkan dengan tanpa penggantian. Campuran aspal dengan penggantian agregrat halus dengan limbah serbuk besi sebesar 25\% lebih memiliki indikasi lebih mantap dibandingkan tanpa pengantian agregrat halus.

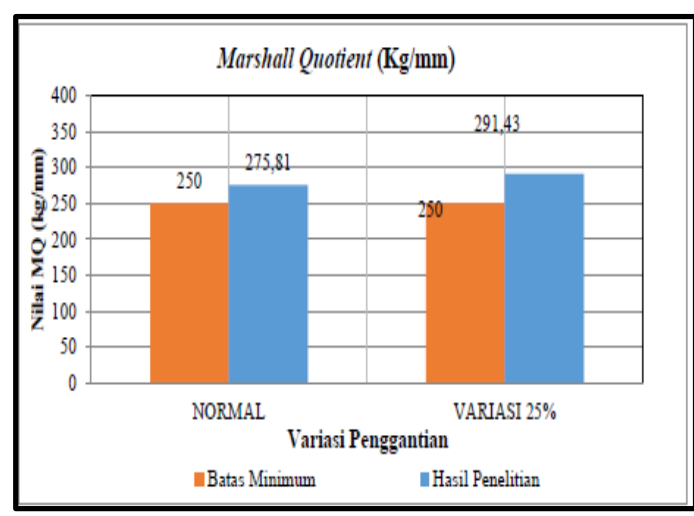

Gambar 6. Grafik Hubungan MQ dengan Variasi Penggantian dan Kondisi Normal

\section{KESIMPULAN}

Berdasarkan hasil penelitian dapat disimpulkan:

1. Pada variasi penggantian limbah serbuk besi $0 \%$ didapatkan kadar aspal optimum sebesar 5,6\%

2. Pada variasi penggantian limbah serbuk besi $25 \%$ didapatkan kadar aspal optimum sebesar $4,6 \%$.

3. Persentase terbaik pada penggantian agregat halus dengan limbah serbuk besi terdapat pada kadar penggantian sebesar $25 \%$ dari berat campuran.

4. Variasi $25 \%$ lebih unggul dalam pemenuhan syarat-syarat parameter Marshall.

5. Terjadi penghematan penggunaan aspal sebesar 17,86\% ketika agregrat halus diganti dengan limbah serbuk besi sebesar $25 \%$.

6. Limbah serbuk besi dapat dimanfaatkan sebagai pengganti agegrat halus dalam campuran aspal dengan kadar maksimum $25 \%$.

\section{DAFTAR PUSTAKA}

Amal, A. S. 2011. Pemanfaatan Getah Karet pada Aspal AC 60/70 terhadap Stabilitas Marshall pada Asphalt 
Treated Base (ATB). Media Teknik Sipil. Vol. 9. No. 1. hal 9.

Daryus, A. 2008. Diktat Kuliah Proses

Produksi, http://ft.unsada.ac.id. diakses 28 April 2016 (Pukul 20.36 WIB).

Direktorat Jenderal Bina Marga. 2010. Spesifikasi Umum Bidang Jalan dan Jembatan. Revisi 3. Divisi VI, Jakarta.

Saodang, H. 2005. Perancangan

Perkerasan Jalan Raya. Nova,

Bandung.
Siswosoebrotho, B.I., Ginting, K., dan Soedirjo, T.L. 2010. Workability and Resilient Modulus of Asphalt Concrete Mixtures Containing Flaky Aggregates Shape. Journal of the Eastern Asia Society for Transportation Studies.Vol.6.

Sukirman, S. 2007. Campuran Aspal Panas. Granit, Bandung. 
ISSN 2086-9045 